\title{
Structure and composition of fish assemblages from São Sebastião Channel tide pools, southwestern Atlantic
}

\author{
Gabriela Pastro $^{1,2}$, Gustavo Muniz Dias ${ }^{I}$ \& Fernando Zaniolo Gibran ${ }^{I}$ \\ ${ }^{1}$ Universidade Federal do ABC, São Bernardo, SP, Brazil \\ ${ }^{2}$ Corresponding author: Gabriela Pastro, e-mail: gabriela.pastro@gmail.com
}

PASTRO, G., DIAS, G.M., GIBRAN, F.Z. Structure and composition of fish assemblages from São Sebastião Channel tide pools, southwestern Atlantic. Biota Neotropica. 16(3): e20150128. http://dx.doi.org/10.1590/16760611-BN-2015-0128

\begin{abstract}
Organisms living in tide pools in the intertidal zone are exposed to daily and abrupt changes in temperature, dissolved oxygen, $\mathrm{pH}$ and salinity, during tidal cycles. Fish assemblages in tide pools are usually very different from those in surrounding areas; resident species exhibit morphological and ecological adaptations to deal with such a variable environment. In this study, we described the environmental conditions and the fish diversity and composition from four tide pools at the continental margin of the São Sebastião Channel, São Sebastião (23⒋ $\left.23^{\circ} 54^{\prime} \mathrm{S} ; 4^{\circ} 19^{\prime}-45^{\circ} 30^{\prime} \mathrm{W}\right)$, in southeastern Brazil. Monthly, from January to December 2011, we sampled four tide pools (12 samples per pool), applying a standard protocol to record environmental variables, and visual censuses to record abundance, richness and composition of fish assemblages. Environmental and fish data were compared among tide pools and periods throughout the year (warm and cold) using both univariate and multivariate analyses of variance. Tide pools showed significant environmental differences, mainly in area, volume and complexity of substrata. We observed 13 species of fishes (10 families), which belong to five trophic guilds (roving herbivores, territorial herbivores, mobile invertebrate feeders, omnivores and carnivores). Density and richness of fish were almost constant during the studied period, except for a reduction in fish density in São Francisco's Beach during a cold period. However, assemblages from the sampled tide pools differed from each other in composition and relative abundance of species, resulting in four distinct assemblage structures. Bathygobius soporator was the dominant species in most of the tide pools, corresponding to $66 \%$ of all recorded fish. The tide pool from Baleeiro's Point was intermediate in size, but was covered by a complex algae community and supported the most diverse fish assemblage, suggesting that habitat complexity may contribute to the diversity of fish.
\end{abstract}

Keywords: Subtropical fish, intertidal zone, environmental factors, species richness, Southeastern Brazil.

PASTRO, G., DIAS, G.M., GIBRAN, F.Z. Estrutura e composição das assembleias de peixes de poças de marés do Canal de São Sebastião, Atlântico sudoeste. Biota Neotropica. 16(3): e20150128. http://dx.doi. org/10.1590/1676-0611-BN-2015-0128

Resumo: Organismos que habitam poças na zona entre marés estão sujeitos a mudanças diárias e abruptas na temperatura, oxigênio dissolvido, $\mathrm{pH}$ e salinidade durante os ciclos das marés. Por isso, as assembleias de peixes dessas poças são geralmente bem distintas daquelas das áreas adjacentes, do infralitoral, apresentando espécies residentes com adaptações morfológicas e ecológicas para lidar com tal ambiente variável. Neste estudo, descrevemos e comparamos as condições ambientais e a diversidade e composição da ictiofauna de quatro poças de marés

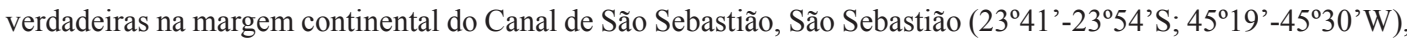
sudeste do Brasil. Mensalmente, de janeiro a dezembro de 2011, amostramos quatro poças (12 amostras por poça), aplicando um protocolo padrão para registrar as variáveis ambientais, e censos visuais para registrar a abundância, riqueza e composição da assembleia de peixes. Dados abióticos e da ictiofauna foram comparados entre poças de maré e períodos do ano (quente e frio) usando análises de variância univariadas e multivariadas. As poças de marés diferiram uma das outras principalmente em área, volume e complexidade do substrato. Observamos 13 espécies de peixes (10 famílias) pertencentes a cinco guildas tróficas (herbívoros vágeis, herbívoros territoriais, invertívoros, onívoros e carnívoros). A densidade e riqueza de peixes foram praticamente constantes ao longo do período estudado, exceto pela redução na densidade de peixes observada na poça da Praia de São Francisco durante o período frio. Entretanto, as assembleias das quatro poças de maré diferiram uma das outras quanto à composição e abundância relativa das espécies, resultando em quatro poças com diferentes estruturas de assembleias. $\mathrm{O}$ amboré Bathygobius soporator foi a espécie dominante na maioria das localidades, correspondendo a $66 \%$ de todos os peixes registrados. A poça da Ponta do Baleeiro apresentou tamanho intermediário, mas esteve coberta por uma complexa comunidade de algas e abrigou a assembleia de peixes mais diversa nesse estudo, sugerindo que a complexidade de habitat pode contribuir para a diversidade de peixes.

Palavras-chave: peixes subtropicas, entremarés, fatores ambientais, riqueza de espécies, sudeste do Brasil. 


\section{Introduction}

Tide pools are formed during low tides when water is retained in depressions in rocky or sandy shores, and serve as a refuge for living organisms during intertidal zone exposure (Griggs 2007). Because of their cyclic isolation during low tides, organisms living in tide pools are exposed to rapid changes in physical-chemical conditions (i.e. temperature, salinity and incident irradiance) that can be more or less marked depending on the time of year, making tide pools a diversified, but very selective habitats for organisms adapted to such oscillations (Fuji 1988, Horn et al. 1999, Griggs 2007). Even small differences in the size, depth and position of tide pools through the intertidal gradient can affect the diversity and structure of their associated communities. For instance, taxon richness can be affected by tide pool height and depth (Firth et al. 2014). Large and deep tide pools located close to the subtidal fringe are usually more stable and support more diverse benthic and nektonic assemblages (e.g. Godinho \& Lotufo 2010). On the other hand, pools more distant from the subtidal fringe are exposed to extreme environmental conditions, such as lower oxygen concentration and, thus, tide pools spatially close may be more similar (e.g. Rosa et al.1997).

Substrate composition of tide pools is another factor that affects the species richness and abundance of fishes (e.g. Arakaki et al. 2014). For example, pools of non-limestone rock formations tend to support more abundant and diverse tide pool assemblages than those composed of limestone at the same latitude. As a global pattern, tropical areas tend to support a more diverse community than subtropical or temperate areas. Southwestern Atlantic subtropical intertidal zones are mainly composed of rocky shores formed by igneous and/or metamorphic rocks. At these sites, local assemblages of fishes are generally influenced by interactions among larval availability and effectiveness of recruitment, as well as many levels and frequencies of disturbances, predation pressures and resource competition, being strongly context-dependent (Sale 1991a, 1991b, Rocha et al. 2005, Robertson et al. 2006, Sale 2006, Gibran \& Moura 2012).

Studies on organisms from tide pools have focused on settlement patterns (e.g. Beckley 1985), population dynamics (e.g. Sideman \& Mathieson 1985, Emson \& Whitfield, 1989), a single species or genera (e.g. Jonhsson 1994, Valentine et al. 2007), larval supply and recruitment (e.g. Pfister 1996), diversity (e.g. Leon et al. 1993, Barreiros et al. 2004), bottom-up and top-down effects on ecosystem functioning (e.g. Menge 2000, Methratta 2004, Masterson et al. 2008) and, more recently, on ecophysiology vs. environmental conditions concerning microbial communities or experimental ecology (e.g. Nguyen \& Byrne 2014, Ntougias 2014). The diversity and composition of fish assemblages from tide pools have been studied in different regions, mainly at temperate latitudes (e.g. Arruda 1979, Mahon \& Mahon 1994, Beja 1995) and for most of the studied regions there is a positive relationship between pool size and fish assemblage attributes such as species richness, abundance and biomass. At the southwestern Atlantic, studies on intertidal fishes are mostly faunal surveys (e.g. Almeida 1973, Rosa et al. 1997, Machado et al. 2015), but in the last decade this has changed, particularly in the Northeast (e.g. Cunha et al. 2007, Cunha et al. 2008, Godinho \& Lotufo 2010) and Southeast Brazil (e.g. Barreiros et al. 2004, Macieira \& Joyeux 2011), with many studies focusing on community ecology of tide pools (but see Soares et al. 2013 for an ecomorphological approach).
Tide pool fishes can be divided into: (1) true residents, which inhabit these sites permanently including Gobiidae and Blennidae families (Gibson 1982); (2) partial residents, generally juveniles of several families as Labridae (Scarinae), Pomacentridae and Chaetodontidae, in addition to some species of economic interest from families Lutjanidae, Epinephelidae and Haemulidae (Gibson 1982, Mahon \& Mahon 1994, Cunha et al. 2007); and (3) occasional, those whose occurrence is only accidental or sporadic (Mahon \& Mahon 1994, Cunha et al. 2007). True residents generally display morphological and/or physiological traits (such as tolerance to salinity changes, and pelvic fins modifications for better stability) as adaptations to permanent life in such peculiar habitats (see Zander et al. 1999). Generally, these individuals are rarely found at the infralittoral, because the tide pools are their principal habitat, even at high tide. In a different way, juveniles of partial residents use these habitats to obtain food and protection during critical development phases; so, tide pools also contribute to fish diversity outside the pools (Horn et al. 1999).

Marine construction and other human activities are responsible for the increasing loss of coastal habitats. By being located in an area of transition between the terrestrial and marine environment, tide pools are subject to more impacts and disturbances than more remote areas of the coast. The dynamics of their community structures can be easily tampered with, especially when changes occur to the local hydrodynamics, which leads to bottom-up effects that reach the fish assemblages (e.g. Freitas et al. 2009). Within this framework, this study aims to characterize and compare four subtropical tide pools based on their environmental variables and fish assemblage composition and abundances. The study was conducted in a poorly managed region that suffers severe impacts from an expanding seaport, oil terminals, sewage discharge, dredging and coastal development (Gibran \& Moura 2012).

\section{Material and Methods}

\section{Study area}

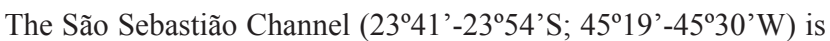
a $25 \mathrm{~km}$ strait in the northern coast of São Paulo State, southeastern Brazil, located between the São Sebastião Island and the mainland (Figure 1). The coastline of the São Sebastião Channel has several tide pools. However, most of those are very small, lacking macroorganisms, or are not completely isolated as "true pools" from the adjacent areas (personal observations during sampling). The only isolated tide pools, during low tide periods, in which we observed macroorganisms at the study area were the four pools studied here and hence restricting our sample size. The pools are located at different sites along the Channel: São Francisco's Beach (SF), Pitangueiras's Beach (PB), Baleeiro's Isthmus (BI) and Baleeiro's Point (BP) (Figure 1). Pitangueiras's Beach, Baleeiro's Isthmus and Baleeiro's Point are located inside no-take Marine Protected Areas (MPAs); the latter two are associated with the Center for Marine Biology, University of São Paulo (CEBIMar-USP) and, thus, have better access to control and implemented conservation policies. Baleeiro's Point and Baleeiro's Isthmus are located parallel to the coast and are $80 \mathrm{~m}$ apart. Baleeiro's Point and Baleeiro's Isthmus are 800 m away from Pitangueiras's Beach and 10 km from São Francisco's Beach (Figure 1). 


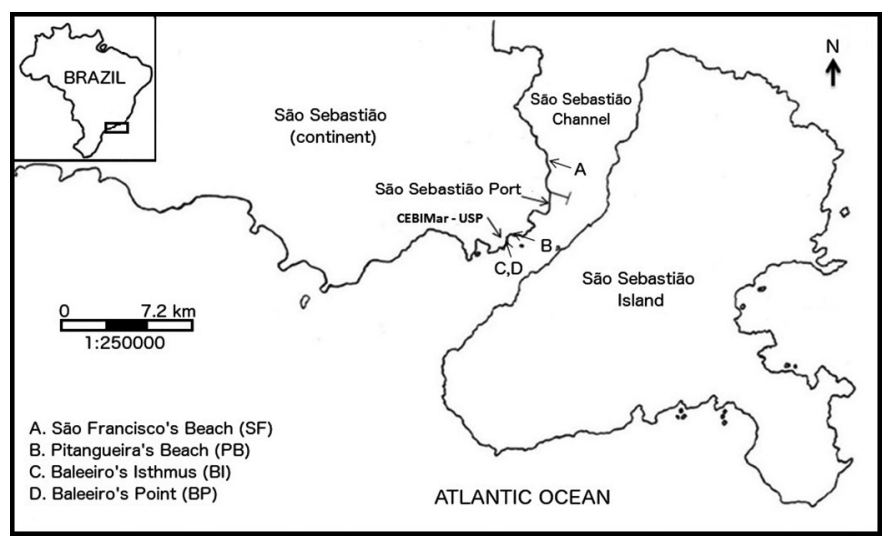

Figure 1. Sampled sites A, B, C, D at the continental margin of São Sebastião Channel, southeastern Brazil. Sites B, C and D are inside a protected area. Modified from Gibran (2010) and (Gibran \& Moura (2012).

\section{Sampling design}

We sampled between January and December 2011 (92 hours of fieldwork). Samples were diurnal, monthly, replicated for each tide pool (12 samples per pool, totaling 48 samples in a year), and performed during 3-4 consecutive days always during low spring tides. The protocol included measures of the environmental variables and visual censuses of fish assemblages as described in the next sections.

\section{Environmental variables}

During each sampling interval we recorded biotic (percent of algal cover, benthic complexity, richness and abundance of fishes) and abiotic variables (perimeter, average depth and average rugosity of tide pools, number of crevices and type and proportion of mineral substrata). To estimate the average depth of tide pools, we measured depth in five haphazardly selected locations within each tide pool. We calculated rugosity using the method suggested by Macieira \& Joyeux (2011), considering linear and real distances along one segment on the length of each tide pool. Surface areas of tide pools were estimated by adding up triangular areas of known sides, until the whole pool was measured. Tide pool volume was estimated by calculating the product of surface area and average depth.

We visually estimated the algal cover on a scale ranging between 0 and $100 \%$ with intervals of ten points (see Bennett \& Griffiths 1984). Substrate types were categorized as sand, gravel or rock and were measured by the same method described above. To record the benthic complexity, the benthic cover was scored based on the percent cover of dominant organisms (cf. Gibran \& Moura 2012): (0) bare rock, sediment or little cover of filamentous and encrusting calcareous algae; (1) uniform cover of up to two dominant species (e.g. barnacles, Sargassum spp., mussels); (2) at least three dominant benthic cover species; (3) diversified, colorful and heterogeneous benthic cover with no obviously dominant species.

\section{Visual censuses of fish assemblages}

We determined species richness, abundance and composition of fishes from visual censuses (12 samples per pool, totaling 48 samples in a year) with the observer outside the pools and always with good water visibility to see the bottom and the edge of each pool. To ensure that all fishes were recorded we also checked all crevices and hiding places manually or with a stick. Each census lasted between 10-15 minutes depending on the size and number of fishes of the sampled pool. When species identification was not possible during census, we temporarily collected and photographed the individuals for subsequent determination. Fish density was calculated by dividing the number of individuals of each species by tide pool volume. Fishes were then classified according to: (1) level of association with the pools (i.e. permanent, partial or occasional residents) based on Gibson (1982), Mahon \& Mahon (1994) and Cunha et al. (2007); (2) vertical distribution in the water column (i.e. benthic, nektobenthic or nektonic) according to Lincoln et al. (2009); and (3) trophic guild according to Ferreira et al. (2004). For species whose juveniles and adults belong to different trophic guilds, only the guild of the observed life phase was considered.

\section{Statistical analysis}

To compare environmental conditions among tide pools we used normalized environmental variables to build a similarity matrix among samples using Euclidian distance to provide a general overview of similarities among pools. We tested multivariate differences among pools using analysis of similarity (ANOSIM) and the environmental variables that most contributed to the differences were identified using the SIMPER procedure. We also performed univariate ANOVA using each sampled variable, both biotic and abiotic, followed by post-hoc pair wise comparisons using a Tukey test.

Fish density and species richness data were $\log \mathrm{x}+1$ transformed to achieve parametric prerequisites of normality and homoscedasticity and then compared among tide pools and periods (warm/wet and cold/dry) using a two-way ANOVA on monthly replicates. Pairwise comparisons were performed using a Tukey post-hoc test.

The warm/wet period corresponded to the Austral Spring and Summer months (January to March and October to December) while the cold/dry period corresponded to Austral Autumn and Winter months (April to September). Our aim in considering the period effect was not to discuss seasonality of fish assemblage or to attribute the differences observed in time to specific environmental conditions since we did not replicate the seasons or have a proper test of environmental conditions effects on fish assemblages. However, including periods (warm/wet and cold/dry) as a factor, allowed us to increase the amount of data variation explained by our test, and thus to better understand the variation of fish assemblages within the studied period and among tide pools.

We used Bray-Curtis distances to calculate the similarities among fish assemblages to perform an nMDS plot (Clarke 1993) and a PERMANOVA test with 999 permutations (Anderson 2001), considering tide pool and periods (warm/wet and cold/dry) as factors. Significant sources of variation were subjected to pairwise comparisons with 999 permutations. To compare the multivariate dispersions of samples among tide pools we used a PERMDISP analysis. Taxonomic groups responsible for differences among-tide pools and periods were identified using the SIMPER procedure. SIMPER was restricted to the first three ranked taxa holding a contribution for the total variance of $8 \%$ or higher.

\section{Results}

The four studied tide pools differed from each other regarding the environmental variables (ANOSIM, Global $\mathrm{R}=0.61, \mathrm{p}=0.001$, all pairwise $\mathrm{p}<0.05$ ) mainly in area, volume and composition of the 
substrata (Table 1). PB is a small and shallow tide pool composed of rocks and several crevices, most of it covered by turf algae (90\%); BP is a tide pool with intermediate area and volume, and also has a high proportion of algae $(90 \%)$, while SF and BI are large tide pools covered by sand with few algae (30-35\% coverage). BP had the most diverse benthic cover, being dominated ( $75 \%$ coverage) by a diversified, colorful and heterogeneous benthic community with no obviously dominant species (level 3 of benthic complexity), while the remaining tide pools were covered (76-90\%) by a uniform cover of up to two dominant species (level 1).

We recorded 2,557 fish belonging to 13 species (10 families) and to five of the eight trophic categories: roving herbivores, territorial herbivores, mobile invertebrate feeders, omnivores and carnivores. Most fishes (60 to $83 \%$ of total abundance) were permanent residents, except in BP where the abundance of permanent and partial residents was similar, respectively $37 \%$ and $46 \%$ of the total. Occasional species corresponded on average to $0-15 \%$ of the total abundance. At all sites juvenile fishes were abundant ( $\mathrm{SF}=42 \%$; $\mathrm{PB}=62 \%$; $\mathrm{BI}=42 \%$; $\mathrm{BP}=$ $44 \%$ of total). In PB and BI, juveniles from permanent resident species were more abundant than non-residents, but in SF and BP we observed the opposite. According to vertical distribution in the water column we recorded six species of benthic, five nektobenthic and two nektonic fishes (Table 2).

The most abundant species was Bathygobius soporator (Valenciennes 1837), corresponding to $66 \%$ of fishes recorded, followed by Diplodus argenteus (Valenciennes 1830) (12\%) and Mugil curema (Valenciennes 1836) (10\%). Ctenogobius boleosoma (Jordan \& Gilbert 1882), Malacoctenus spp., Parablennius pilicornis (Cuvier 1929), Scartella cristata (Linnaeus 1758), Sphoeroides greeleyi (Gilbert 1900), Stegastes fuscus (Cuvier 1830) and Micrognathus crinitus (Jenyns 1842) were only observed in BP. Altogether, tide pools were dominated almost always by a single species (B. soporator or $M$. curema), with the exception of BP, which was dominated by two species, B. soporator and $D$. argenteus (Figure 2).

During the warm period all of the studied tide pools held higher densities of fishes than the cold period. However, during the cold period the density of fishes was very low in SF (Tables 3 and 4). During the whole study BP held the richest assemblage with $4.9 \pm 0.64$ (mean \pm $\mathrm{SE}$ ) fish species per sample. The mean species richness from BI, PB and SF did not differ from each other, ranging from 1.08 to 1.9 species per sample (Tables 3 and 4). BP along with SF displayed more functional groups than $\mathrm{PB}$ and $\mathrm{BI}$, which were dominated by carnivores (Figure 3 ). Carnivores and omnivores were present in all tide pools, and carnivores were the more abundant guild. Roving and territorial herbivores were recorded just in SF and BP, respectively (Figure 3).

The four tide pools displayed different fish assemblages (all pairwise tests $\mathrm{p}<0.05$ ) with dissimilarities ranging from $39 \%$ between $\mathrm{PB}$ and $\mathrm{BI}$ to $68 \%$ between SF and BP (Table 5; Figure 4). The assemblages from the tide pools SF and BP were more variable through the year period than assemblages from BI and PB (PERMDISP, $p<0.001$ ). The species that contributed the most to the differences in fish assemblages among tide pools were $B$. soporator and $A$. saxatilis, which were abundant in $\mathrm{PB}, \mathrm{BI}$ and $\mathrm{BP}$ but scarce or absent in SF; $D$. argenteus that occurred in $\mathrm{SF}, \mathrm{BI}$ and BP, but not in PB; and M. curema, which was only observed in SF (SIMPER analysis, Table 5). Temporal variation of the fish assemblages was caused mainly by larger abundance of $B$. soporator during the warm period and by the larger abundance of $D$. argenteus during the cold period (SIMPER analysis, Table 5).

\section{Discussion}

Each tide pool studied here had peculiar characteristics, and even the spatially closest pools showed significant environmental differences, mainly in area, volume and complexity of substrata. Tide pools were dominated mostly by juveniles of permanent residents and common species of the southeastern Brazil, such as Bathygobius soporator and Abudefduf saxatilis. Density and richness of fish showed a small amount of variation during the studied period, except for a reduction in fish density in SF during the cold period. However, the proportion of the most abundant fish within tide pools was extremely variable, resulting in four distinct assemblage structures. The tide pool with the least algal coverage (BI), even being among the largest tide pool in our study area, supported a less diverse fish assemblage than a tide pool of intermediate size covered by a more diversified benthic community (BP), suggesting that habitat complexity may contribute to the diversity of fish. The other large tide pool, SF, was also covered by algae, and had only four species of fish. However, each species belongs to a different functional group, resulting in a high functional diversity. On the other hand, the shallowest pool (PB), held only two fish species and was dominated by Bathygobius soporator.

The studied pools had smaller size and volume than those found in other regions of southeastern Brazil. Even the largest tide pools (SF and $\mathrm{BI}$ ) had a smaller area and volume than those from tropical areas from the Southwestern Atlantic, such as those from the northeastern coast of Brazil (e.g. Rosa et al. 1997, Cunha et al. 2008, Godinho \& Lotufo 2010). In our study area, rocky shores are formed by igneous

Table 1. Mean and standard error of the values obtained for tide pool characteristics and the contributions of different mineral substrates in the four studied tide pools, together with the $\mathrm{p}$ and F values obtained through statistical analysis, where: SF = São Francisco's Beach, PB = Pitangueiras's Beach, BI = Baleeiro's Isthmus, $\mathrm{BP}=$ Baleeiro's Point

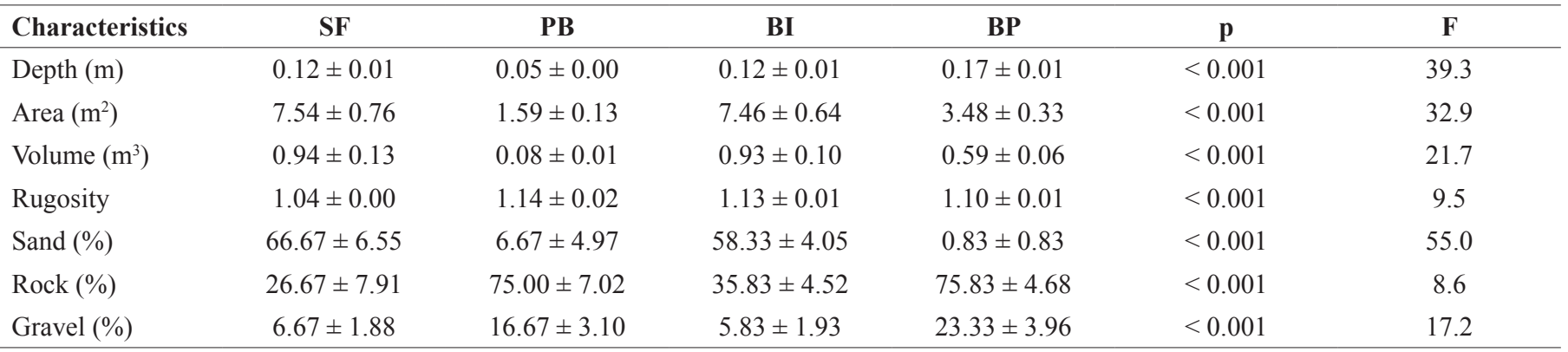


Spatial and temporal variation on tide pools

Table 2. Total fish abundance recorded per tide pool between January and December 2011 with classification of trophic guilds (see reference below), vertical distribution and level of association. $\mathrm{OMN}=$ omnivore, $\mathrm{TERH}=$ territorial herbivore, $\mathrm{MIF}=$ mobile invertebrate feeder, $\mathrm{CAR}=$ carnivore, $\mathrm{ROVH}=\mathrm{roving}$ herbivore, $\mathrm{N}=$ nektonic, $\mathrm{B}=$ benthic, $\mathrm{NC}=$ nektobenthic, $\mathrm{RPA}=$ resident partial, $\mathrm{RPE}=$ resident permanent, $\mathrm{O}=$ occasional, $\mathrm{SF}=\mathrm{Sa} o$ Francisco's $\mathrm{Beach}, \mathrm{PB}=\mathrm{Pitangueiras}$ 's Beach, BI = Baleeiro's Isthmus, BP = Baleeiro's Point.

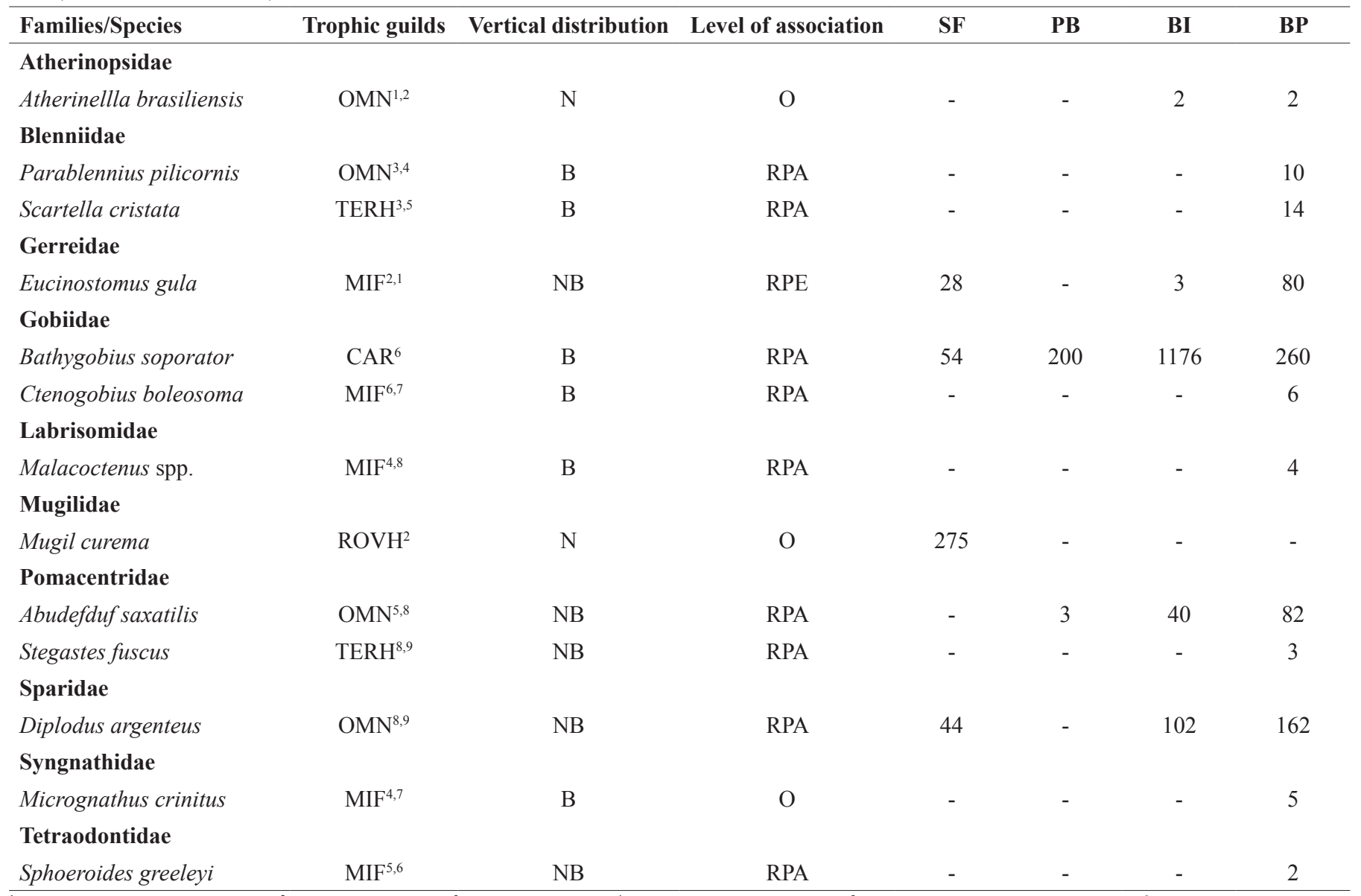

${ }^{1}$ Figueiredo \& Menezes (1978), ${ }^{2}$ Paiva et al. (2008), ${ }^{3}$ Dinslaken (2008), ${ }^{4}$ Halpern \& Floeter (2008), ${ }^{5}$ Chaves \& Monteiro-Neto (2009), ${ }^{6}$ Corrêa \& Uieda (2007), ${ }^{7}$ Carvalho-Filho (1999), ${ }^{8}$ Floeter et al. (2007), ${ }^{9}$ Ferreira et al. (2004).

and/or metamorphic rocks with tide pools occurring inside natural depressions, while on the northeastern coast and other reef-forming areas, the tide pools are mainly formed by large crevices in sandstone reefs (i.e. higher structural complexity). Also, tide pools from tropical areas tend to support more diverse assemblages than tide pools from temperate areas, regardless the substrata. In our study, we observed 13 species of fishes, as already reported for other tide pools under similar latitude, while those in the tropics had at least 40 species (e.g. Rosa et al. 1997, Cunha et al. 2008). These differences from other studied areas could be a sampling effect, since we only studied four tide pools, which may restrict the generalization of our conclusions. On the other hand, as far as we know, the tide pools studied here are the only real pools from the continental portion of the São Sebastião Channel.

The small volume of the São Sebastião Channel tide pools may contribute to their low species richness, as expected by the species/ area relationship. Larger pools, besides having a larger area, exhibit a more temporally constant habitat, allowing less tolerant species to occur, which increases diversity (Rosa et al. 1997). However, in our study, the largest tide pools ( $\mathrm{SF}$ and $\mathrm{BI}$ ) held a less specious assemblage than $\mathrm{BP}$, which is a tide pool of intermediate size, differing from other studies, where abundance and richness are positively correlated to tide pool volume (Cunha et al. 2007). Other factors, such as tide pool isolation, hydrodynamics and algal cover, may interact with volume and area to determine the distribution and structure of fish assemblages inside tide pools (Godinho \& Lotufo 2010, Macieira \& Joyeux 2011). In the intertidal zone, intense water turbulence restricts biological activities such as feeding and reproduction of some benthic fishes, such as labrisomids and blenniid species like Malacoctenus spp. and Parablennius pilicornis. Besides being protected from wave and wind actions, BP is also mostly covered by a diverse benthic community, allowing the occurrence of fishes with specific diets, such as the territorial herbivorous damselfish Stegastes fuscus. On the other hand, the largest tide pools SF and BI are covered by sand and bare rock, that may restrict the occurrence of some species. Although PB is the smallest pool, it is also the most elevated, which isolates the fish assemblages and reduces water inflow and colonization during high tides, resulting in an assemblage with only two species. Considering that we only sampled four tide pools and that those differed from each other on several physical and biological attributes, a larger sample size is necessary to properly test how tide pool size and complexity interact to determine fish diversity.

While species composition might differ among tide pools around the world, Gobiidae and Bleniidae families are frequently reported as dominant in several localities, such as Japan (Arakaki et al. 2014), 

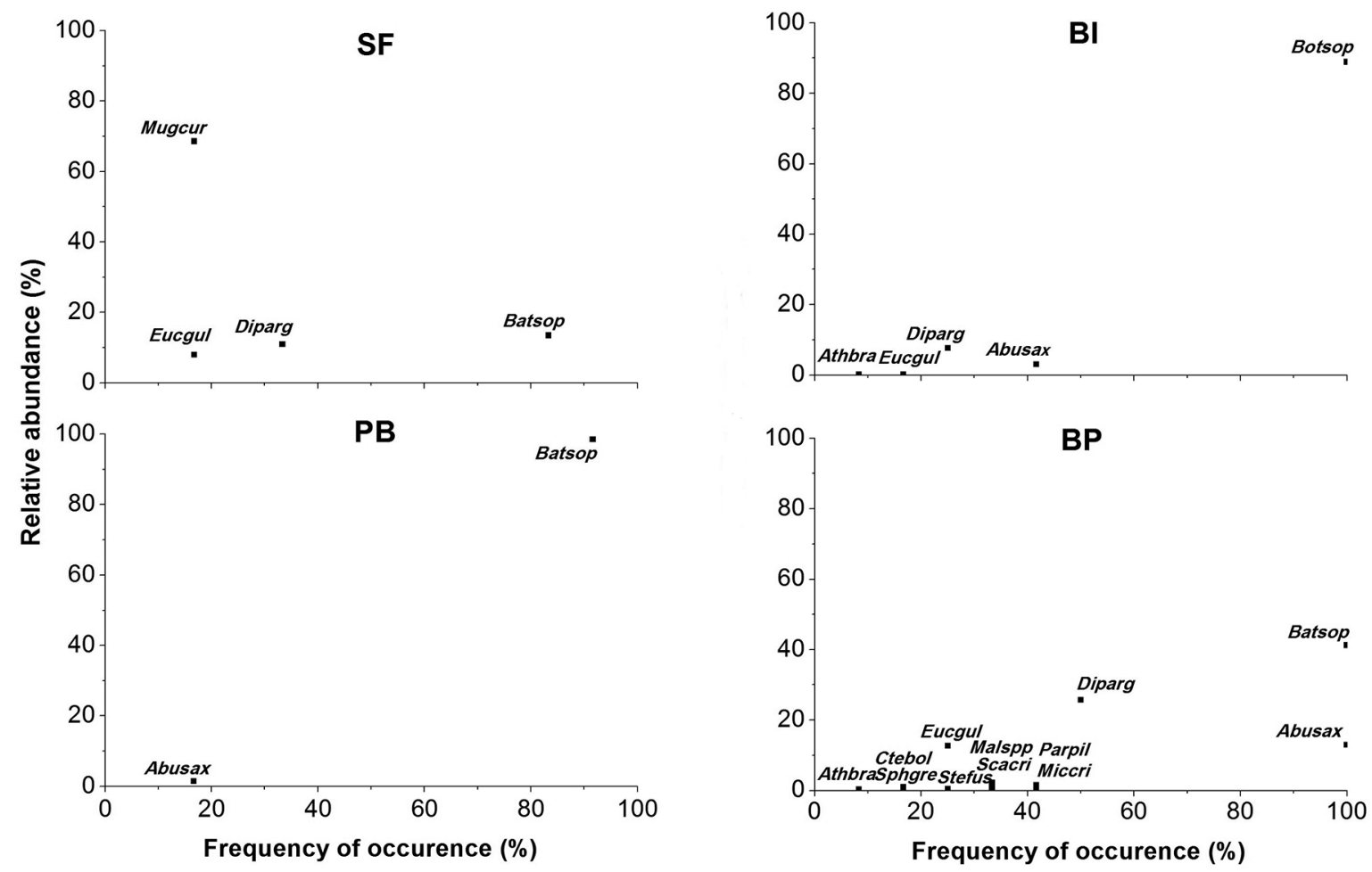

Figure 2. Relative abundance and frequency of occurrence of fish fauna in the tide pools of São Francisco's Beach (SF), Pitangueiras's Beach (PB), the Baleeiro's Isthmus (BI) and Baleeiro's Point (BP), between January and December 2011. Species codes: first three letters of the genus name followed by the first three letters of the specific epithet: Abusax = Abudefduf saxatilis, Athbra = Atherinella brasiliensis, Batsop = Bathygobius soporator, Ctebol $=$ Ctenogobius boleosoma, Diparg $=$ Diplodus argenteus, Eucgul $=$ Eucinostomus gula, Malspp $=$ Malacoctenus spp., Miccri = Micrognathus crinitus, Mugcur = Mugil curema, Parpil $=$ Parablennius pilicornis, Scacri $=$ Scartella cristata, Sphgre $=$ Sphoeroides greeleyi, Stefus $=$ Stegastes fuscus. Tide pools codes: SF $=$ São Francisco's Beach, PB $=$ Pitangueiras's Beach, BI $=$ Baleeiro's Isthmus, BP = Baleeiro's Point.

Table 3. Fish density and species richness in the four studied tide pools (average \pm standard error)

\begin{tabular}{|c|c|c|c|}
\hline \multirow{2}{*}{$\begin{array}{l}\text { Tide pool } \\
\text { Period }\end{array}$} & \multicolumn{2}{|c|}{ Abundance (individuals/m $/ \mathbf{m}^{3}$ ) } & \multirow{2}{*}{ Richness (number of species) } \\
\hline & Warm/wet & Cold/dry & \\
\hline São Francisco's Beach (SF) & $67.7 \pm 30.3$ & $9.81 \pm 4.1$ & $1.5 \pm 0.2$ \\
\hline Baleeiro's Isthmus (BI) & $136.6 \pm 30.7$ & $121.9 \pm 10.3$ & $1.9 \pm 0.2$ \\
\hline Baleeiro’s Point (BP) & $119.7 \pm 13.0$ & $77.2 \pm 19.4$ & $4.9 \pm 0.6$ \\
\hline
\end{tabular}

Table 4. Analyse of variance considering the effects of tide pools and period (warm/wet or cold/dry) on fish density and species richness and PERMANOVA on the structure of fish assemblage. $* \mathrm{p}<0.05, * * \mathrm{p}<0.01, * * * \mathrm{p}<0.001$.

\begin{tabular}{lccccccccc}
\hline & \multicolumn{3}{c}{ Species richness } & \multicolumn{3}{c}{ Fish density } & \multicolumn{3}{c}{ Fish assemblage } \\
Source & Df & MS & F & Df & MS & F & Df & MS & Pseudo-F \\
\hline Season (SE) & 1 & 1.69 & 1.05 & 1 & 0.06 & 0.26 & 1 & 93172.9 & $3.52^{*}$ \\
Tide pool (TP) & 3 & 36.41 & $22.69 * * *$ & 3 & 2.41 & $9.70^{* * *}$ & 3 & 9600.9 & $10.66^{* *}$ \\
SE x TP & 3 & 0.63 & 0.76 & 3 & 0.80 & $3.24 *$ & 3 & 1055.5 & 1.17 \\
Error & 40 & 1.60 & & 40 & 0.25 & & 39 & 900.18 \\
\hline
\end{tabular}

Mediterranean Sea (Macpherson 1994) and Hawaiian Island (Cox et al. 2011). The most abundant species in this study, B. soporator, is also abundant in other tide pools of the Brazilian coast (e.g. Rosa et al. 1997, Barreiros et al. 2004). In the studied area, it accounts for the preponderance of permanent residents, followed by Scartella cristata, $P$. pilicornis and Ctenogobius boleosoma. Permanent resident fishes have morphological, physiological and behavioral adaptations to live in these environments (Floeter et al. 2001, Barreiros et al. 2004, Macieira 2008), and $B$. soporator is rarely found outside tide pools (see Gibran \& Moura 2012). On the other hand, occasional visitants are less frequent and abundant, because they enter the pools during high tides and are trapped when the tide recedes. They are more frequent in pools closer to the 


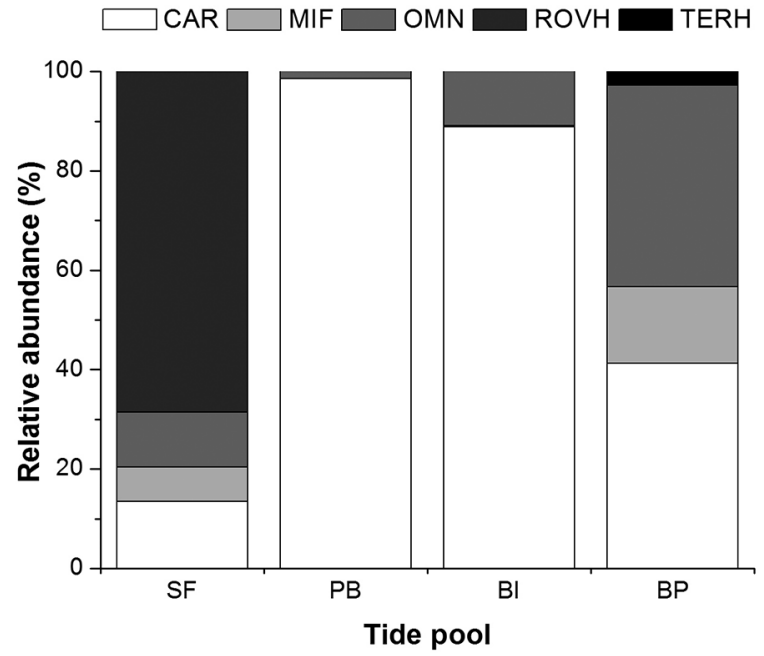

Figure 3. Relative abundance of each trophic guild present in the tide pools of São Francisco's Beach (SF), Pitangueiras's Beach (PB), the Baleeiro's Isthmus (BI) and Baleeiro's Point (BP), between January and December 2011. CAR = carnivore, $\mathrm{MIF}=$ mobile invertebrate feeder, $\mathrm{OMN}=$ omnivore, $\mathrm{ROVH}=$ roving herbivore, TERH $=$ territorial herbivore.

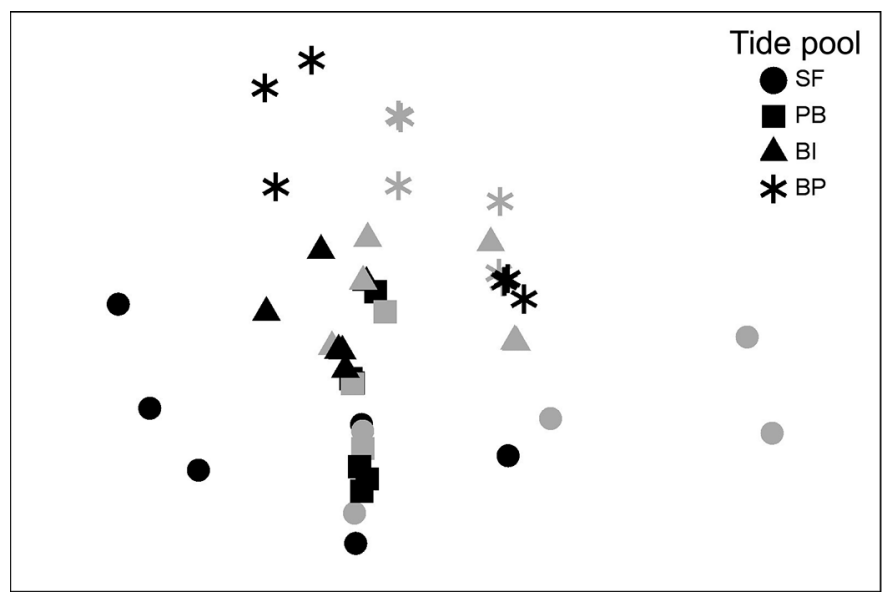

Figure 4. Non-metric multidimensional scalling plot of fish assemblages from tide pools of São Francisco's Beach (SF), Pitangueiras's Beach (PB), the Baleeiro's Isthmus (BI) and Baleeiro's Point (BP) in the studied tide pools. Black symbols represent the Warm/Wet season, while Grey symbols represent the Cold/Dry season. Stress $=0.12$.

infralittoral (Barreiros et al. 2004), as SF and BL. The high percentage of occasional individuals in SF result from numerous juveniles of Mugil curema, that can be attributed to the schooling behavior of this species, while in BI, Sphoeroides greeleyi, Micrognathus crinitus and Atherinella brasiliensis were the most abundant occasional species.

Considering the degree of conservation of each pool, we propose that despite three pools being in protected areas (BP, BI and PB) and two with controlled access (BP and $\mathrm{BI}$ ), this factor was not strongly related to diversity and trophic complexity. In this study, intrinsic factors of each pool, such as algal coverage (primary productivity), may be the most responsible for the distribution of species found, but a proper test of this hypothesis is needed. The importance of the temporal variation of fish assemblages was also small when compared to the variation among tide pools. The richness of fish was constant during the whole study and we only observed differences in the abundance of fish for

Table 5. Simper analyses showing the contribution of species for the dissimilarity among tide pools and periods of the year, where: SF = São Francisco's Beach, $\mathrm{PB}=$ Pitangueiras's Beach, $\mathrm{BI}=$ Baleeiro's Isthmus, $\mathrm{BP}=$ Baleeiro's Point.

\begin{tabular}{lr}
\hline SF x PB & Dissimilarity \\
Species & Contributio \\
Bathygobius soporator & 42.5 \\
Diplodus argenteus & 26.2 \\
Mugil curema & 14.3
\end{tabular}

\section{SF x BI}

Species

Bathygobius soporator

Diplodus argenteus

Abudefduf saxatilis

\section{SF $x$ BP}

Species

Abudefduf saxatilis

Diplodus argenteus

Bathygobius soporator

PB x BI

Species

Bathygobius soporator

Abudefduf saxatilis

Diplodus argenteus

\section{PB x BP}

Species

Abudefduf saxatilis

Diplodus argenteus

Bathygobius soporator

\section{BI x BP}

Species

Diplodus argenteus

Abudefduf saxatilis

Bathygobius soporator

Warm/Wet x Cold/Dry

Species

Bathygobius soporator

Diplodus argenteus

Abudefduf saxatilis

the tide pool in SF. The differences in the organization of the fish assemblages observed between the warm and cold period seems to be related to variation in the abundance of the most common species and not to a turnover of species during the year, and was more pronounced

\section{Dissimilarity $=62 \%$ \\ Contribution (\%) \\ 49.4 \\ 19.8 \\ 8.8}

\author{
Dissimilarity $=68 \%$ \\ Contribution (\%) \\ 23.2 \\ 19.0 \\ 15.1
}

Dissimilarity $=39 \%$
Contribution $(\%)$

50.4

23.8

19.2

Dissimilarity $=\mathbf{5 8 \%}$
Contribution $(\mathbf{\%})$
25.2
24.6
8.7

Dissimilarity $=\mathbf{5 0} \%$

Contribution (\%)

22.0

18.8

17.5
Dissimilarity $=\mathbf{5 1} \%$
Contribution (\%)
27.7
23.0
17.3


in SF and BP, which were the pools with the smallest abundance of fish during the study. This small variation of the fish assemblage during the year can be related to the small number of species in tide pools, to an intrinsic variation of conditions during the studied period, or to the study area location in a subtropical zone, in which temporal variation seems to play an underestimated small role in the diversity of fish when compared to tropical areas.

Because most of the partial resident individuals are recruits and juveniles, tide pools seem to work as nursery sites for nektobenthic species that use tide pools for reproduction and early development (Horn et al. 1999). Because of (1) their importance to fishes that do not occur at the infralittoral zone and for juvenile fishes from adjacent seawater during reproduction, and also (2) of their location in a transition zone between ocean and mainland, highly influenced by continental development and human activities, tide pools need to be considered as a peculiar marine habitat and also considered during Marine Protected Area (MPA) establishment (see Myres et al. 2011). Our study described the fish assemblages from the few real tide pools from the continental portion of the São Sebastião Channel and shows that while most of the species occurring in the four tide pools are very similar, there is a large differentiation between fish assemblages among tide pools caused mainly by differences in the abundance of B. soporator, A. saxatilis and $D$. argenteus.

\section{Acknowledgements}

We thank the CEBIMar-USP and Universidade Federal do ABC for infrastructure and logistical support; R. F. Benassi and T. A. Jesus for loan of equipment for dissolved oxygen; N. P. Ghilardi-Lopes to valuable suggestions on graduate work research, G. H. Pereira-Filho for valuable suggestions on the manuscript and L. Hiebert for English review. This paper results from GP undergraduate work research and was supported by CAPES/UFABC.

\section{References}

ALMEIDA, V.G. 1973. New records of tidepool fishes from Brazil. Pap Avulsos Zool 26(14):187-191.

ANDERSON, M.J. 2001. A new method for non-parametric multivariate analysis of variance. Austral Ecol 26(1):32-46.

ARAKAKI, S., TSUCHIYA, M. \& TOKESHI, M. 2014. Testing latitudinal patterns of tidepool fish assemblages: local substrate characteristics affect regional-scale trends. Hydrobiologia, 733(1):45-62.

ARRUDA, L.M. 1979. Specific composition and relative abundance of intertidal fish at two places on the Portuguese coast (Sesimbra and Magoito, 1977-78). Arq Mus Bocage, 6:325-342.

BARREIROS, J.P., BERTONCINI, A., MACHADO, L., HOSTIM-SILVA, M. \& SANTOS, R.S. 2004. Diversity and seasonal changes in the ichthyofauna of rocky tidal pools from Praia Vermelha and São Roque, Santa Catarina, Brazil. Braz Arch Biol Techn, 47:291-299.

BECKLEY, L.E. 1985. Tide-pool fishes: recolonization after experimental elimination. J Exp Mar Biol Ecol, 85(3):287-295.

BEJA, P.R. 1995. Structure and seasonal fluctuations of rocky littoral fish assemblages in south-western Portugal: implications for otter prey availability. J Mar Biol Assoc UK, 75(4):833-847.

BENNETT, B.A. \& GRIFFITHS, C.L. 1984. Factors affecting the distribution, abundance and diversity of rock-pool fishes on the Cape Peninsula, South Africa. S Afr J Zool, 19:97-104.
CARVALHO-FILHO, A. 1999. Peixes: Costa Brasileira. 3nd edition. São Paulo, Editora Melro Ltda.

CHAVES, L.C.T. \& MONTEIRO-NETO, C. 2009. Comparative analysis of rocky reef fish community structure in coastal islands of south-eastern Brazil. J Mar Biol Assoc UK, 89(3):609-619.

CLARKE, K. R. 1993. Nonparametric multivariate analyses of changes in community structure Austral J Ecol, 18(1):117-143.

CORREAA, M.O.D.A. \& UIEDA, V.S. 2007. Diet of the ichthyofauna associated with marginal vegetation of a mangrove forest in southeastern Brazil. Iheringia, Sér Zool, 97(4):486-497.

COX, T.E., BAUMGARTNER, E., PHILIPPOFF, J. \& BOYLE, K.S. 2011. Spatial and vertical patterns in the tidepool fish assemblage on the island of Oahu. Environ Biol Fish, 90(4):329-342.

CUNHA, E.A, CARVALHO, R.A.A., MONTEIRO-NETO, C., MORAES, L.E. \& ARAÚJO, M.E. 2008. Comparative analysis of tidepool fish species composition on tropical coastal rocky reefs at state of Ceará, Brazil. Iheringia, Sér Zool, 98(3):379-390.

CUNHA, F.E.A., MONTEIRO-NETO, C. \& NOTTINGHAM, M.C. 2007. Temporal and spatial variations in tidepool fish assemblages of the northeast coast of Brazil. Biota Neotrop, 7(1):95-102.

DINSLAKEN, F.D. 2008. Estrutura da comunidade de peixes de costão rochoso na Ilha de Santa Catarina. Unpublished Work Completion for Graduation, Universidade Federal de Santa Catarina, Santa Catarina, Brazil.

EMSON, R.H. \& WHITFIELD, P.J. 1989. Aspects of the life history of a tide pool population of Amphipholis squamata (Ophiuroidea) from South Devon. J Mar Biol Assoc UK, 69(1):27-41.

FERREIRA, C.E.L, FLOETER, S.R., GASPARINI, J.L., FERREIRA, B.P. \& JOYEUX, J.C. 2004. Trophic structure patterns of Brazilian reef fishes: a latitudinal comparison. J Biogeogr, 31(7):1093-1106.

FIGUEIREDO, J.L \& MENEZES, N.A. 1978. Manual de Peixes Marinhos do Sudeste do Brasil. II. Teleostei (1). São Paulo, Museu de Zoologia da Universidade de São Paulo.

FIRTH, L.B., SCHOFIELD, M., WHITE, F.J., SKOV, M.W. \& HAWKINS, S.J. 2014. Biodiversity in intertidal rock pools: Informing engineering criteria for artificial habitat enhancement in the built environment. Mar Environ Res, 102:122-130.

FLOETER, S.R., GUIMARÃES, R.Z.P., ROCHA, L.A., FERREIRA, C.E.L., RANGEL, C.A. \& GASPARINI, J.L. Gasparini. 2001. Geographic variation in reef-fish assemblages along the Brazilian coast. Global Ecol Biogeogr, 10:423-431

FLOETER, S.R., KROHLING, W., GASPARINI, J.L., FERREIRA, C.E.L. \& ZALMON, I.R.. 2007. Reef fish community structure on coastal islands of the southeastern Brazil: the influence of exposure and benthic cover. Environ Biol Fish, 78:147-160.

FREITAS, M.C.D., VIEIRA, R.H.S.D.F. \& ARAÚJO, M.E.D. 2009. Impact of the construction of the harbor at pecém (Ceará, Brazil) upon reef fish communities in tide pools. Braz Arch Biol Tech, 52(1):187-195.

FUJI, A. 1988. Measuring wave force on a rocky intertidal shore. Bulletin of the Faculty of Fisheries Hokkaido University, 39(4):257-261.

GIBRAN, F.Z. 2010. Habitat partitioning, habits and convergence among coastal nektonic fish species from the São Sebastião Channel, southeastern Brazil. Neotrop Ichthyol, 8(2):299-310.

GIBRAN, F.Z \& MOURA, R.L. 2012. Structure and composition of rocky shore fishes across a nearshore to open ocean gradient in southeastern Brazil. Neotrop Ichthyol, 10(2):369-382.

GIBSON, R.N. 1982. Recent studies on the biology of intertidal fishes. Oceanogr Mar Biol, 20:363-414.

GODINHO, W.O. \& LOTUFO, T.M.C. 2010. Local v. microhabitat influences on the fish fauna of tidal pools in north-east Brazil. J Fish Biol, 76:487-501.

GRIGGS, G. 2007. Tidepools, formation and rock type. Pp. 586-589. In: Encyclopedia of Tidepools \& Rocky Shores (M.W. Denny \& D.D. Gaines, eds.). California, University of California Press. 
HALPERN, B.S. \& FLOETER, S.R. 2008. Functional diversity responses to changing species richness in reef fish communities. Mar Ecol-Progr Ser, 364:147-156.

HORN, M.H, MARTIN, K.L.M. \& CHOTKOWKI, M.A. 1999. Intertidal Fishes - Life in Two Worlds. San Diego, Academic Press.

JONHSON, P.R. 1994. Tidal rhythm of cyst formation in the rock pool ciliate Strombidium oculatum Gruber (Ciliophora, Oligotrichida): A description of the functional biology and an analysis of the tidal synchronization of encystment. J Exp Mar Biol Ecol, 175(1):77-103.

LEON, H., FRAGOSO, D., LEON, D., CANDELARIA, C., SERVIERE, E. \& GONZÁLEZ-GONZÁLEZ, J. 1993. Characterization of tidal pool algae in the Mexican Tropical Pacific coast. Hydrobiologia, 260/261:197-205.

LINCOLN, R.J., BOXSHALL, G.A. \& CLARK, P.F. 2009. Diccionario de Ecología, Evolutíon y Taxonomía. México, Fondo de Cultura Económica.

MACHADO, F.S., MACIEIRA, R.M., ZULUAGA GÓMEZ, M.A., COSTA, A.F., MESQUITA, E. \& GIARRIZZO, T. 2015. Checklist of tidepool fishes from Jericoacoara National Park, southwestern Atlantic, with additional ecological information. Biota Neotrop, 15(1):1-9. http://dx.doi. org/10.1590/1676-06032015011114

MACIEIRA, R.M. 2008. Estrutura de comunidade e distribuição espacial dos peixes das poças de maré em um recife do Atlântico sudoeste, Brasil. Unpublished Master's Thesis, Universidade Federal do Espírito Santo, Espírito Santo, Brazil.

MACIEIRA, R.M.A \& JOYEUX, J-C. 2011. Distribution patterns of tidepool fishes on tropical flat reef. Fish B-NOAA, 109(3):305-315.

MACPHERSON, E. 1994. Substrate utilization in a Mediterranean littoral fish community. Mar Ecol-Progr Ser, 114:211-218.

MAHON, R. \& MAHON, S.D. 1994. Structure and resilience of a tidepool fish assemblages at Barbados. Environ Biol Fish, 41:171-190.

MASTERSON, P., ARENAS, F.A., THOMPSON, R.C. \& JENKINS, S.R. 2008. Interaction of top down and bottom up factors in intertidal rockpools: effects on early successional macroalgal community composition, abundance and productivity. J Exp Mar Biol Ecol, 363(1):12-20.

MENGE, B.A. 2000. Top-down and bottom-up community regulation in marine rocky intertidal habitats. J Exp Mar Biol Ecol, 250(1):257-289.

METHRATTA, E.T. 2004. Top-down and bottom-up factors in tidepool communities. J Exp Mar Biol Ecol, 299(1):77-96.

MYRES, M.C, WAGNER, J. \& VAUGHAN, C. 2011. Long-term comparison of the fish community in a Costa Rican rochy shore marine reserve. Rev Biol Trop, 59(1):233-246.
NGUYEN, H.D. \& BYRNE, M. 2014. Early benthic juvenile Parvulastra exigua (Asteroidea) are tolerant to extreme acidification and warming in its intertidal habitat. J Exp Mar Biol Ecol, 453:36-42.

NTOUGIAS, S. 2014. Phylogeny and ecophysiological features of prokaryotes isolated from temporary saline tidal pools. Ann Microbiol, 64:599-609.

PAIVA, A., CHAVES, P. \& ARAÚJO, M. 2008. Estrutura e organização trófica da ictiofauna de águas rasas em um estuário tropical. Rev Bras Zool, 25(4):647-661.

PFISTER, C.A. 1996. The role and importance of recruitment variability to a guild of tide pool fishes. Ecology, 1928-1941.

ROBERTSON, D.R., KANG, F., MOURA, R.L., VICTOR, B.C. \& BERNARDI, G. 2006. Mechanisms of speciation and faunal enrichment in Atlantic parrotfishes. Mol Phylogenet Evol, 40:795-807.

ROCHA, L A., ROBERTSON, D.R., ROMAN, J. \& BOWEN, B.W. 2005. Ecological speciation in tropical reef fishes. P Roy Soc B-Biol Sci, 272:573-579.

ROSA, R.S., ROSA, I.L. \& ROCHA, L.A. 1997. Diversidade da ictiofauna de poças de maré da praia do Cabo Branco, João Pessoa, Paraíba. Brasil. Rev Bras Zool, 14(1):201-212.

SALE, P.F. 1991a. The Ecology of Fishes on Coral Reefs. London, Academic Press, Inc.

SALE, P.F. 1991b. Reef fish communities: open nonequilibrial systems. In: The Ecology of Fishes on Coral Reefs (SALE, P.F., ed.). San Diego, CA, Academic Press, p.564-598.

SALE, P.F. 2006. Coral Reef Fishes: Dynamics and Diversity in a Complex Ecosystem. San Diego, Academic Press, Inc.

SIDEMAN, E.J. \& MATHIESON, A.C. 1985. Morphological variation within and between natural populations of non-tide pool Fucus distichus (Phaeophyta) in New England. J Phycology, 21(2):250-257.

SOARES, B.E., RUFFEIL, T.O.B. \& MONTAG, L.F.A. 2013. Ecomorphological patterns of the fishes inhabiting the tide pools of the Amazonian Coastal Zone, Brazil. Neotrop Ichthyol, 11(4):845-858.

VALENTINE, P.C., CARMAN, M.R., BLACKWOOD, D.S. \& HEFFRON, E.J. 2007. Ecological observations on the colonial ascidian Didemnum sp. in a New England tide pool habitat. J Exp Mar Biol Ecol, 342(1):109-121.

ZANDER, C.D., NEIDER, J. \& MARTIN, K. 1999. Vertical distribution patterns. In: Intertidal Fishes - Life in Two Worlds (M.H. Horn, K.L.M. Martin \& M.A. Chotkowki, eds.). San Diego, CA, Academic Press, p.26-53. 